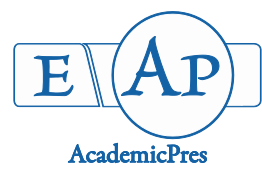

\title{
Effects of Fertilizer Application and Successive Harvesting on Clipping Yield, Phytochemical Contents and Antioxidant Activity of Cynodon dactylon (L.) Pers.
}

\author{
Vella A.C. FUNG, Januarius GOBILIK, Devina DAVID* \\ University Malaysia Sabah, Faculty of Sustainable Agriculture, Locked Bag No.3, 90509 Sandakan, Sabah, \\ Malaysia; vellafung@gmail.com;jgobilik@ums.edu.my;ddevina@ums.edu.my (*orrespondingauthor)
}

\begin{abstract}
The present study aimed to investigate the effects of fertilizer application and successive harvesting on phytochemical contents and antioxidant activities of Cynodon dactylon, a medicinal Bermuda grass in Sabah (Malaysia). Three fertilizers of two nitrogen concentrations were used in the experiment. The grass was harvested successively three times at five-weeks interval. Grass treated with $25 \mathrm{~kg} \mathrm{~N} / \mathrm{ha} /$ month from the first harvest was found to have the highest clipping yield. Successive harvesting decreased the dry matter production of the grass irrespective of $\mathrm{N}$ concentration applied. Total saponin and alkaloid contents of the grass were increased by a combination treatment of fertilizer type $\times$ rate $\times$ harvesting; total flavonoid content was increased by fertilizer type $\times$ harvesting treatments; however, total phenolic content was not affected by any of the treatment or combination of the treatments. Both of the antioxidant assays (DPPH and FRAP) indicated that antioxidant activity of the grass was increased by fertilizer rate $\times$ harvesting treatments. There was a significant correlation found between total phenolic and flavonoid contents and antioxidant activities, suggesting that these two secondary metabolites may contribute to the antioxidant property of the grass. Overall, the obtained data indicated that the described treatments could be used to manipulate the production and accumulation of bioactive compounds of $C$. dactylon.
\end{abstract}

Keywords: Bermuda grass; cutting frequency; nitrogen rate; organic/ inorganic fertilizer

\section{Introduction}

The application of organic and inorganic fertilizers improves soil fertility and thus plant growth and development. More specific, the chemical composition and concentration of the fertilizers will affect the biosynthesis and composition of secondary compounds in the plants (Hallmann and Rembiałkowska, 2012). The manipulation of fertilizer application has been reported to increase the phytochemical and bioactive contents of medicinal plants, such as Cosmos caudatus, Hypericum perforatum and Ocimum basilicum (Hassan et al., 2012; Farshchi et al., 2014; Onofrei et al., 2017). In organic or inorganic fertilizers, nitrogen $(\mathrm{N})$ has been one of the major components important for plant growth and development, meaning this element has an important role in affecting the phytochemical and bioactive contents of plants (Vashisth $e t$ al., 2017; Barroso et al., 2018). In addition, successive harvesting has also been one of the factors that affects chemical properties and dry matter yield of medicinal plants. Frequent harvesting has been reported to affect the phytochemical contents and antioxidant activities of Stevia rebaudiana Bertoni (Tavarini et al., 2015) and Chicorium spinosum L. (Petropoulos et al., 2017). Successive harvesting at 35-day and 30-day interval has been found to decrease the dry matter yield of Moringa oleifera Lam (Amaglo et al., 2007) and Talinum triangulare (Jacq.) Willd (Brasileiro et al., 2015) respectively. Other than nitrogen application and harvesting frequency, planting time (Brasileiro et al., 2015), geographical location and maturity stages (Gull et al., 2012), cultivar and harvesting time (Zou et al., 2012) could also affect the biosynthesis of secondary metabolites in plants.

Cynodon dactylon is one of the important medicinal plants documented in traditional medicine system around the world and has been claimed by tribe or traditional communities to have various medicinal values (Nagori and Solanki, 2011). It has also been reported to have contributed to pharmacological development in recent years, such as, in the production of antioxidant, antimicrobial, wound healing, antidiabetic, anti-cancer, anti-malarial and anti-chikungunya agents (Khlifi et al., 2013; Chandel and Kumar, 2015; Murali et al., 2015). 
There are many ecotypes of $C$. dactylon found in Sabah (Malaysia) (Gobilik et al., 2013). Several ecotypes have been reported to show antimicrobial activities against clinical pathogens (Abdullah et al., 2012). To date, however, there is no study carried out to explore the effect of agricultural practices on the secondary metabolites production and antioxidant activity of this grass.

In the present study, the effects of two common agricultural practices, fertilizer application and harvesting, on the production of secondary metabolites and antioxidant activities of Cynodon dactylon in Sabah (Malaysia) are reported.

\section{Materials and Methods}

Grass planting, maintenance and dry matter yield assessment

The experiment was carried out in rain shelter as a factorial tray-experiment of 3 fertilizers $(\mathrm{F}) \times 2 \mathrm{~N}$ application rate $(\mathrm{R})$ and 5 replicates arranged in a Completely Randomized Design. The harvesting $(\mathrm{H})$ treatment was included as a within subject factor to the fertilizer treatment. The stolons of the grass were collected from a wild population of $C$. dactylon that has already been reported to produce medicinally important metabolites (Abdullah et al., 2012). Twenty-five stolons were planted per tray $(46 \mathrm{~cm} \times 34 \mathrm{~cm} \times 15 \mathrm{~cm})$ on a medium consisting of top soil and sand (1:9). Inorganic NPK 15-15-15 (F1), and two types of organic NPK 8-8-8 (F2), and NPK 5-5-5 (F3) were used as the fertilizers. The fertilizers were applied monthly at two rates: $12.5 \mathrm{~kg} \mathrm{~N} / \mathrm{ha}(\mathrm{R} 1)$ and $25.0 \mathrm{~kg} \mathrm{~N} / \mathrm{ha}$ (R2). Grass sprouted from the stolon was let to grow for 5 weeks before it was trimmed. New shoots were let to resprout in the next 5 weeks. From week 10 and onwards, grass in each tray was harvested three times $(\mathrm{H} 1, \mathrm{H} 2$ and $\mathrm{H} 3$ ) at 5-week interval; all stolons of 4-cm above the medium were harvested. At each harvest, grass collected from each tray was cleaned under running tap water and dried in an oven at $50^{\circ} \mathrm{C}$ until attained a constant weight or at least 24 hours to obtain the dry matter weight of the clippings.

Preparation of extract for phytochemical and antioxidant activity analyses

The dried grass was grinded to powder at 3,000 rpm using a mechanical grinder, kept in air tight container and stored at $4{ }^{\circ} \mathrm{C}$. For the quantification of total saponin and alkaloid, the crude extract was prepared following the procedures described by Mohadjerani et al. (2014). A total of $50 \mathrm{~g}$ of the grass powder was macerated at room temperature in $100 \mathrm{ml}$ of $80 \%(\mathrm{v} / \mathrm{v})$ ethanol for $24 \mathrm{~h}$. The extract was filtered and concentrated at $55^{\circ} \mathrm{C}$ under reduced pressure using rotary evaporator (Heidolph). The crude extract was kept at $-20{ }^{\circ} \mathrm{C}$ for further use. For the quantification of total phenolic and flavonoids, the crude extract was prepared following a slightly modified method explained by Ibrahim et al. (2013). The powder $(0.1 \mathrm{~g})$ of the grass was soaked in $10 \mathrm{ml}$ of $80 \%(\mathrm{v} / \mathrm{v})$ ethanol and kept in water bath shaker at $50^{\circ} \mathrm{C}$ and $120 \mathrm{rpm}$ for $2 \mathrm{~h}$. The extract was filtered using Whatman filter paper No.1 (Whatman Ltd., England). The extract was directly used for the total phenolic, total flavonoid and antioxidant analyses.
Total saponin and alkaloid contents

The total saponin content (TSC) of the crude extract was assessed using the method described by Sudha and Srinivasan (2013). It was expressed as diosgenin equivalent per gram of the crude extract (mg DE gm ${ }^{-1}$ crude extract) used in the test. The total alkaloid content (TAC) of the extract was determined using the technique explained by Shamsa et al. (2008). It was expressed as atropine equivalent per gram of the crude extract (mg AE gm ${ }^{-1}$ crude extract) used in the test.

\section{Total phenolic and flavonoid contents}

The total phenolic content (TPC) of the crude extract was measured following the method described by Singleton et al. (1999). It was expressed as mg gallic acid equivalent per

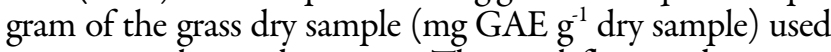
to prepare the crude extract. The total flavonoid content (TFC) of the crude extract was quantified using the technique explained by Ibrahim et al. (2013). It was expressed as $\mathrm{mg}$ quercetin equivalent per gram of the grass dry sample ( $\mathrm{mg} \mathrm{QE} \mathrm{g}^{-1}$ dry sample) used to prepare the crude extract.

\section{2, 2-diphenyl-1-picrylhydrazyl Radical Scavenging} Activity (DPPH-RSA)

The DPPH-RSA of the crude extract was assessed to evaluate its antioxidant activity. The evaluation was carried out following the method explained by Fook and Kheng (2009) with a slight modification of the wavelength used, i.e., $518 \mathrm{~nm}$. The final antioxidant activity (AA\%) data were expressed as $\mathrm{IC}_{50}$ values. The $\mathrm{IC}_{50}$ values were interpreted as the concentration of the samples that produced $50 \%$ scavenging DPPH radical $(\mathrm{mg} / \mathrm{ml})$.

\section{Ferric Reducing Antioxidant Power (FRAP)}

FRAP test was used to support the result of the DPPHRSA explained above. FRAP was assessed following the procedures applied by Benzie and Strain (1996). The method used by those authors was based on the reduction of colourless ferric complex $\left(\mathrm{Fe}^{3+}\right.$ tripyridyltriazine) to bluecolored ferrous complex $\left(\mathrm{Fe}^{2+}\right.$ tripyridyltriazine) by the action of electron donating antioxidants at low $\mathrm{pH}$. The reaction was monitored by measuring the change in light absorbance of the substance at $593 \mathrm{~nm}$ wavelength. The result was expressed as the concentration of antioxidant having a ferric reducing ability in $1 \mathrm{~g}$ of the grass dry sample $\left(\mathrm{mM} \mathrm{g}^{-1}\right)$.

\section{Statistical analysis}

Mixed Analysis of Variance (Mixed ANOVA) was performed to infer the effects of fertilizer treatments and successive harvesting on the clipping yield, phytochemical contents and antioxidant activity of the grass. The comparison of between-subject-factor means (fertilizer treatments) was evaluated using Tukey test (at $\mathrm{p} \leq 0.05$ ), and the comparison of within-subject-factor means (successive harvesting) was evaluated using Bonferroni test (at $\mathrm{p} \leq 0.05$ ). All statistical analyses were carried out using SPSS version 21. 
132

\section{Results}

The summary of the effects of fertilizer application and successive harvesting on yield, total saponin, total alkaloid, total phenolic and total flavonoid contents and antioxidant activity of Cynodon dactylon is shown in Table 1.

\section{Clippingyield}

Combination of $\mathrm{R} \times \mathrm{H}$ had significantly increased the clipping yield (Table 1). The highest clipping yield was $4,386.02 \mathrm{~kg} / \mathrm{ha}$, which was found for grass under $\mathrm{R} 2$ at $\mathrm{H} 1$ (Fig.1). These findings, however, were authentic only at $\mathrm{H} 1$. The clipping yields for R1 and R2 decreased significantly after $\mathrm{H} 2$ and $\mathrm{H} 3$.

\section{Total saponin content}

The TSC of the grass was increased by $\mathrm{F} \times \mathrm{R} \times \mathrm{H}$ (Table 1). The highest TSC was $588.49 \pm 17.08 \mathrm{mg}$ DE/g of crude extract, which was found for grass grown under F1 at R2

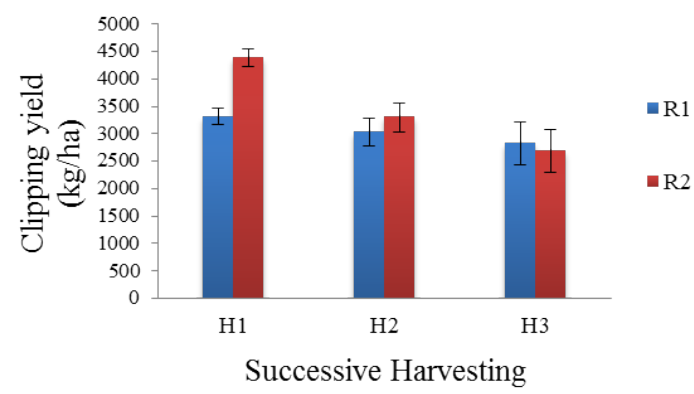

Fig. 1. Effect of fertilizer rate $(\mathrm{R})$ and successive harvesting $(\mathrm{H})$ on clipping yield. Note: R1: $12.5 \mathrm{~kg} \mathrm{~N} / \mathrm{ha} ; \mathrm{R} 2: 25 \mathrm{~kg} \mathrm{~N} / \mathrm{ha}$; $\mathrm{H} 1: 1^{\text {st }}$ harvest; H2: $2^{\text {nd }}$ harvest; H3: $3^{\text {rd }}$ harvest. Error bars represent standard error and $\mathrm{H} 3$ (Fig. 2). This result also showed that TSC increased after $\mathrm{H} 3$ in F1, F2 and F3 treatments regardless of $\mathrm{N}$ application rate $(\mathrm{R})$.

\section{Total alkaloid content}

The TAC of the grass was also increased by $\mathrm{F} \times \mathrm{R} \times \mathrm{H}$ (Table 1) with a little variation of responses. For F1, it increased with increment of $\mathrm{R}$ and $\mathrm{H}$; for $\mathrm{F} 2$, there was no consistent response; for F3, TAC was the highest under R1 and $\mathrm{H} 1$ (Fig. 3). The highest TAC was $23.16 \pm 3.18 \mathrm{mg}$ $\mathrm{AE} / \mathrm{g}$ crude extract, which was found for grass grown under $\mathrm{F} 1$ at $\mathrm{R} 1$ and $\mathrm{H} 3$.

\section{Total phenolic and flavonoid contents}

The production of TPC was not affected by any treatment or combination of the treatments. For TFC, it increased only under $\mathrm{F} \times \mathrm{H}$ (Table 1 ). TFC was the highest under F3 at every harvesting time $(\mathrm{H} 1-\mathrm{H} 3)$ (Fig. 4). The value of TFC under F3 ranged from $47.92 \pm 1.58$ to 49.17 $\pm 1.58 \mathrm{mg} \mathrm{QE} / \mathrm{g}$ dry samples for $\mathrm{H} 1, \mathrm{H} 2$ and $\mathrm{H} 3$.

\section{Antioxidant assay}

The DPPH-RSA indicated that the $\mathrm{IC}_{50}$ of the grass was decreased (e.g. antioxidant capacity increased) by $\mathrm{F} \times \mathrm{R}$ and $\mathrm{R} \times \mathrm{H}$ (Table 1). For $\mathrm{F} \times \mathrm{R}$, the $\mathrm{IC}_{50}$ decreased under $\mathrm{F} 3$ at both R1 and R2 and in fact, F3 led to the lowest $\mathrm{IC}_{50}$ in this study (Fig. 5A). Under F1 and F2, the $\mathrm{IC}_{50}$ decreased only under R1. Similarly, for $\mathrm{R} \times \mathrm{H}$, the $\mathrm{IC}_{50}$ decreased significantly only under R1 (Fig. 5B). For R2, the $\mathrm{IC}_{50}$ was almost similar between $\mathrm{H} 1, \mathrm{H} 2$ and $\mathrm{H} 3$.

Meanwhile, the treatment of $\mathrm{R} \times \mathrm{H}$ also significantly increased the antioxidant activity by FRAP assay. The antioxidant activity of the grass under R1 was increased from $\mathrm{H} 1$ to $\mathrm{H} 3$ (Fig. 5C). The same pattern was observed for R2, however, the FRAP value was lower compared to R1.

Table 1. Effects of fertilizer application and successive harvesting on yield, total saponin, total alkaloid, total phenolic and total flavonoid contents and antioxidant activity of Cynodon dactylon

\begin{tabular}{|c|c|c|c|c|c|c|c|}
\hline Treatments & $\begin{array}{c}\text { CY } \\
(\mathrm{kg} \mathrm{dry} \\
\left.\text { weight ha- }{ }^{-1}\right) \\
\end{array}$ & $\begin{array}{c}\text { TSC } \\
\text { (mg DE g } \\
\text { crude extract) }\end{array}$ & $\begin{array}{c}\text { TAC } \\
\left(\mathrm{mg} \mathrm{AE} \mathrm{g}^{-1}\right. \\
\text { crude extract) }\end{array}$ & $\begin{array}{c}\text { TPC } \\
\text { (mg GAE g } \\
\text { dry sample) }\end{array}$ & $\begin{array}{c}\text { TFC } \\
\text { (mg QE g }{ }^{-1} \text { dry } \\
\text { sample) }\end{array}$ & 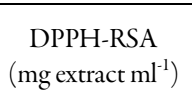 & $\begin{array}{c}\text { FRAP } \\
(\mathrm{mM} \text { Fe }(\mathrm{II}) / \mathrm{g} \\
\text { dry sample) }\end{array}$ \\
\hline \multicolumn{8}{|l|}{ Fertilizer $(\mathrm{F})$} \\
\hline $\mathrm{F} 1$ & $4,270^{\mathrm{a}}$ & $301.89^{\mathrm{a}}$ & $11.67^{\mathrm{a}}$ & 29.10 & $39.52^{b}$ & $1.38^{\mathrm{b}}$ & $559.55^{\mathrm{b}}$ \\
\hline $\mathrm{F} 2$ & $2,960^{\mathrm{b}}$ & $236.52^{b}$ & $12.75^{\mathrm{a}}$ & 29.52 & $42.26^{b}$ & $1.25^{\mathrm{b}}$ & $579.76^{b}$ \\
\hline F3 & $2,538^{\mathrm{b}}$ & $214.01^{\mathrm{c}}$ & $7.90^{\mathrm{b}}$ & 31.20 & $48.68^{a}$ & $1.04^{\mathrm{a}}$ & $650.85^{a}$ \\
\hline \multicolumn{8}{|l|}{ Rate (R) } \\
\hline R1 & $3,056.3$ & $242.65^{b}$ & 11.11 & 30.40 & 43.28 & $1.11^{\mathrm{a}}$ & $630.77^{a}$ \\
\hline $\mathrm{R} 2$ & $3,455.1$ & $258.96^{a}$ & 10.42 & 29.48 & 43.69 & $1.34^{\mathrm{b}}$ & $562.67^{b}$ \\
\hline \multicolumn{8}{|l|}{ Harvesting $(\mathrm{H})$} \\
\hline $\mathrm{H} 1$ & $3,850^{a}$ & $162.87^{\mathrm{c}}$ & $11.06^{b}$ & 30.21 & 43.01 & $1.37^{\mathrm{b}}$ & $546.58^{c}$ \\
\hline $\mathrm{H} 2$ & $3,164^{b}$ & $198.80^{\mathrm{b}}$ & $6.68^{c}$ & 29.37 & 43.53 & $1.19^{\mathrm{a}}$ & $597.25^{b}$ \\
\hline $\mathrm{H} 3$ & $2,753^{b}$ & $390.75^{a}$ & $14.57^{\mathrm{a}}$ & 30.25 & 43.92 & $1.11^{\mathrm{a}}$ & $646.33^{\mathrm{a}}$ \\
\hline \multicolumn{8}{|c|}{ Analysis of variance } \\
\hline F & ** & $* *$ & ** & ns & $* *$ & $* *$ & ** \\
\hline $\mathrm{R}$ & ns & ** & ns & ns & ns & ** & ** \\
\hline $\mathrm{H}$ & ns & $* *$ & ns & ns & ns & $* *$ & $* *$ \\
\hline $\mathrm{F} \times \mathrm{R}$ & ns & ** & ${ }^{* *}$ & ns & ns & ** & ns \\
\hline $\mathrm{F} \times \mathrm{H}$ & ns & ** & ${ }^{* *}$ & ns & $* *$ & ns & ns \\
\hline $\mathrm{R} \times \mathrm{H}$ & ${ }^{* *}$ & ** & ${ }^{* *}$ & ns & ns & $* *$ & ${ }^{* *}$ \\
\hline $\mathrm{F} \times \mathrm{R} \times \mathrm{C}$ & $\mathrm{ns}$ & ${ }^{* *}$ & ** & ns & ns & ns & ns \\
\hline
\end{tabular}




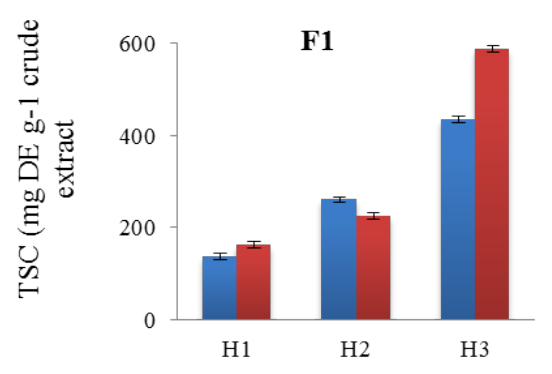

Successive harvesting

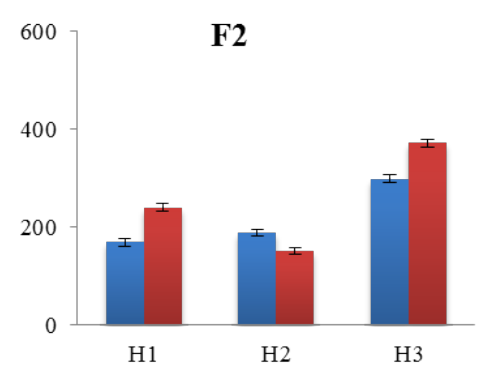

Successive harvesting

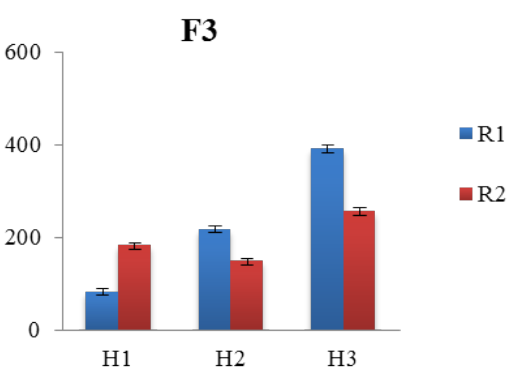

Successive harvesting

Fig. 2. Effect of fertilizer type (F), rate (R) and successive harvesting $(\mathrm{H})$ on total saponin content (TSC). Note: F1: NPK 15-1515; F2: NPK 8-8-8; F3: NPK 5-5-5; R1: $12.5 \mathrm{~kg} \mathrm{~N} / \mathrm{ha} ; \mathrm{R} 2: 25 \mathrm{~kg} \mathrm{~N} / \mathrm{ha} ; \mathrm{H} 1: 1^{\text {st }}$ harvest; H2: $2^{\text {nd }}$ harvest; H3: $3^{\text {rd }}$ harvest. Error bars represent standard error
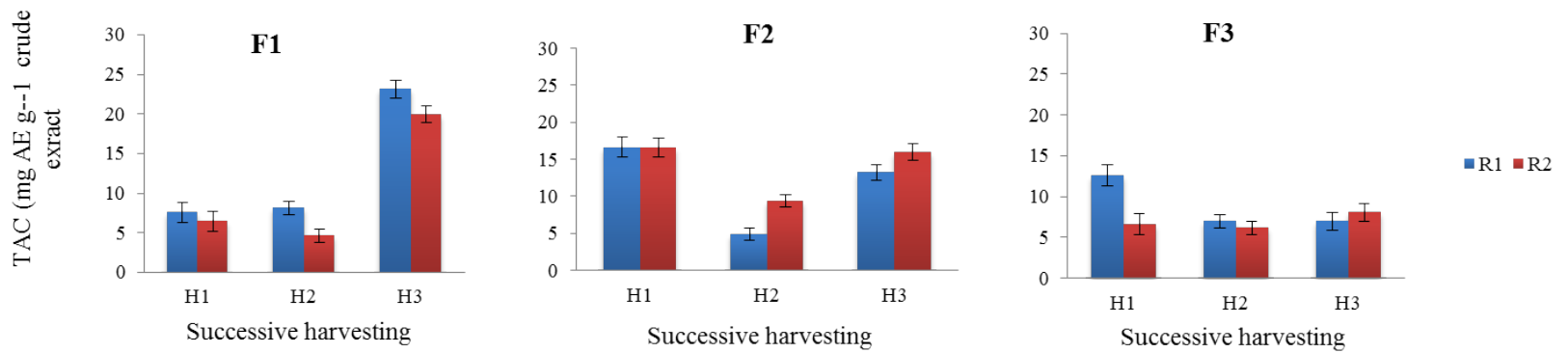

Fig. 3. Effect of fertilizer type $(\mathrm{F})$, rate $(\mathrm{R})$ and successive harvesting $(\mathrm{H})$ on total alkaloid content (TAC). Note: F1: NPK 15-1515; F2: NPK 8-8-8; F3: NPK 5-5-5; R1: $12.5 \mathrm{~kg} \mathrm{~N} /$ ha; R2: $25 \mathrm{~kg} \mathrm{~N} /$ ha; H1: 1st harvest; H2: 2nd harvest; H3: 3rd harvest. Error bars represent standard error

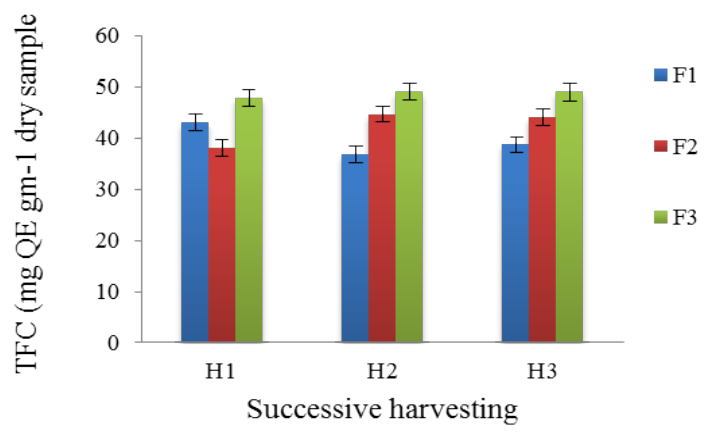

Fig. 4. Effect of fertilizer type (F) and successive harvesting $(\mathrm{H})$ on total flavonoid content (TFC). Note: F1: NPK 15-15-15; F2: NPK 8-8-8; F3: NPK 5-5-5; H1: 1st harvest; H2: 2nd harvest; H3: 3rd harvest. Error bars represent standard error

A)

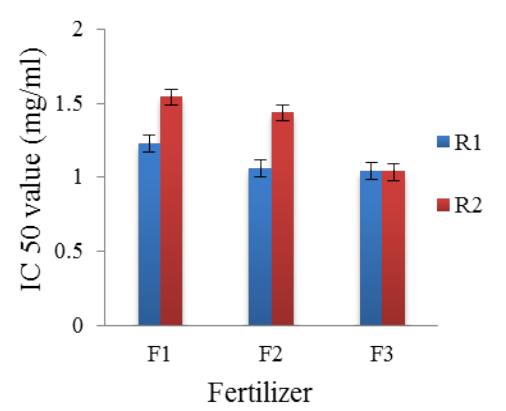

B)

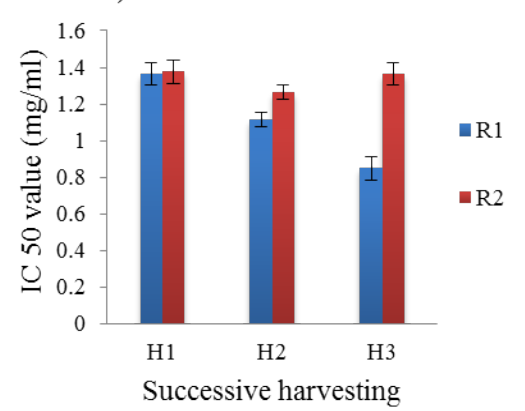

C)

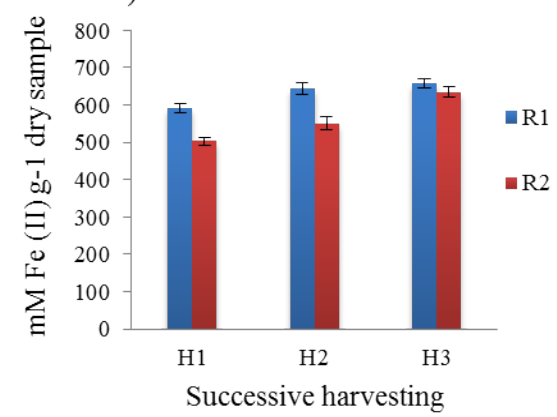

Fig. 5. (A) Effect of fertilizer type (F) and rate (R) on $\mathrm{IC}_{50}$ value; (B) Effect of fertilizer rate $(\mathrm{R})$ and successive harvesting $(\mathrm{H})$ on $\mathrm{IC}_{50}$ value; $(\mathrm{C})$ Effect of fertilizer rate $(\mathrm{R})$ and successive harvesting $(\mathrm{H})$ on FRAP value. Note: F1: NPK 15-15-15; F2: NPK 8-88; F3: NPK 5-5-5; R1: $12.5 \mathrm{~kg} \mathrm{~N} / \mathrm{ha}$; R2: $25 \mathrm{~kg} \mathrm{~N} / \mathrm{ha} ; \mathrm{H} 1: 1^{\text {st }}$ harvest; H2: $2^{\text {nd }}$ harvest; H3: $3^{\text {rd }}$ harvest. Error bars represent standard error 
134

Correlation of TPC, TFC and DPPH-RSA, FRAP

There was a significant negative-correlation between TPC and $\mathrm{IC}_{50} \mathrm{DPPH}(\mathrm{r}=-0.608, \mathrm{p}<0.05)$ and between TFC and $\mathrm{IC}_{50} \mathrm{DPPH}(\mathrm{r}=-0.575, \mathrm{p}<0.01)$ (Table 2).
There was also a significant, but this time positivecorrelation between TPC and FRAP $(\mathrm{r}=0.484, \mathrm{p}<0.01)$ and between TFC and FRAP $(r=0.469, p<0.01)$.

Table 2. Correlation between antioxidant activities (DPPH and FRAP assays) with total phenolic, total flavonoid, total saponin and total alkaloid contents

\begin{tabular}{|c|c|c|c|c|c|c|}
\hline Parameters & 1 & 2 & 3 & 4 & 5 & 6 \\
\hline 1. TPC & 1.000 & & & & & \\
\hline 2. TFC & $0.572^{* *}$ & 1.000 & & & & \\
\hline 3. TSC & -0.211 & 0.031 & 1.000 & & & \\
\hline 4. TAC & -0.101 & -0.447 & 0.275 & 1.000 & & \\
\hline 5. DPPH (IC50 value) & $-0.608^{* *}$ & $-0.575^{*}$ & -0.060 & 0.242 & 1.000 & \\
\hline 6. FRAP assay & $0.484^{*}$ & $0.469^{*}$ & 0.445 & -0.071 & $-0.638^{* *}$ & 1.000 \\
\hline
\end{tabular}
and 0.05 , respectively (2-tailed)

\section{Discussion}

\section{Effects of fertilizer application and harvesting frequency on dry matter yield}

In the present study, it has been expected that plants have a higher dry matter yield at a higher $\mathrm{N}$ application, irrespective of the types of the fertiliser used. The yield has also been reported to decrease with successive harvesting. High cutting frequency has been reported to reduce the dry matter production of grass, for example, Napier grass and hybrid Pennisetums (Manyawu et al., 2003), as well as perennial ryegrass (Lolium perenne L.) and white clover (Trifolium repens L.) (Vinther, 2006). The removal of the above ground growth will limit the capacity of the grass to photosynthesizes, leading to a lacking of carbohydrate for root and rhizome development, as the grass will use up most of the carbohydrate produced to resprout (Aldous and Wilson, 1999; Turgeon, 2008).

\section{Effects of fertilizer application and harvesting frequency on plant secondary metabolites}

The results regarding the positive effect of F1 (NPK 15$15-15)$ especially at a higher $\mathrm{N}$ application rate $(25 \mathrm{~kg}$ $\mathrm{N} / \mathrm{ha}$ ) on TSC of the grass could be associated with the fast release of $\mathrm{N}$ from inorganic fertilizer. It has been reported that the concentration of saponin in the rhizome of Anchomanes difformis (Blume) Engl. increases after an application of only $15 \mathrm{~kg} \mathrm{~N} / \mathrm{ha}$ of NPK 15-15-15 (Rivai et al., 2017). There are, however, some different results reported by other studies. Xia et al. (2016) found that the accumulation of saponin in the roots of Panax notoginseng [(Burk.) F.H. Chen] has been due to an addition of magnesium mineral fertilizer. Ibrahim et al. (2013) reported that an addition of organic fertilizer containing a high concentration of micro nutrients promotes the production of saponin in Labisia pumila (Benthis). Mary and Nithiya (2015) reported a similar trend of response to that of Ibrahim et al. (2013) for Solanum nigrum L.

Similar to TSC, the positive effect of inorganic fertilizer (NPK 15-15-15) on TAC of the grass could be associated with the fast release of $\mathrm{N}$ from inorganic fertilizer. Nitrogen application has been reported to promote alkaloid formation, as nitrogen is an essential element for alkaloid biosynthesis (Gholamhosseinpour et al., 2011). Even so, the requirement has been found to be dissimilar between plants.
A rate of $450 \mathrm{~kg} \mathrm{~N} / \mathrm{ha}$ is required to increase the alkaloid content of guinea grass, Panicum maximum (Jacq.) (Onyeonagu and Ukwueze, 2012). On the other hand, the production of alkaloid in Datura innoxia (Mill.) has been reported to decrease with increment of $\mathrm{N}$ application (AlHumaid, 2005). The study appears to support the interaction between $\mathrm{N}$ application and production of alkaloid in the present study; it was higher at the lower $\mathrm{N}$ application.

The application of organic fertilizer has been reported to improve phenolic and flavonoid production in broccoli (Brassica olaracea, var. Italica) (Naguib et al., 2012), Labisia pumila Benth (Ibrahim et al., 2013) and Lycopersicon esculentum Mill. (Ilupeju et al., 2015). In the present study, the production of TPC in the grass, however, was not affected by either fertilizer type, rate or harvesting frequency. There is no clear explanation for this result based on the information available to the authors. For TFC, the positive effect of the organic fertilizers (NPK 8-8-8 and NPK 5-5-5) is in line with the previous findings. In other words, organic fertilizers could be used to increase flavonoid production in $C$. dactylon. Perhaps, the availability of major and minor elements in the organic fertilizers has contributed to higher production of flavonoid in the grass; this is contrary to the inorganic fertilizer, which consists only N, P and $\mathrm{K}$.

With regard to the effects of successive harvesting on TSC, TAC, TPC and TFC, stress from the cutting may have induced the grass to produce more secondary metabolites. It has been reported that plants produce a higher amount of secondary metabolites as a response to stress, such as, injury stress (Dixon and Paiva, 1995; JacoboVelázquez et al., 2015). Mechanical wounding activates phenylpropanoid metabolism and enhances the production of phenolic compounds (Jacobo-Velázquez et al., 2015). In a plant-environment interaction, flavonoids play a major role for the survival of plants including in defending against biotic and abiotic stresses, such as UV radiations, pathogens and insects (War et al., 2012). Other study has reported that a fortnightly instead of weekly cutting increases the level of alkaloid in horse grass (Zhang et al., 2011). In fact, alkaloid production in grass was reported to be affected even by mowing height (Salminen et al., 2003) and maturity stages (Onyeonagu and Ukwueze, 2012). There is also incidence, however, that successive cutting decreases the antioxidant 
capacity of plants, such as the case in Stevia rebaudiana (Bertoni) and Chicorium spinosum (L.) reported by Tavarini et al. (2015) and Petropoulus et al. (2017), respectively. In the last two studies, the highest antioxidant activity was found for plant extract from the first rather than from the second or third harvest.

\section{Effects of fertilizer application and cutting frequency on} antioxidant activities

In DPPH-RSA assay, a lower $\mathrm{IC}_{50}$ value indicates a higher ability to scavenge free radicals (Kedare and Singh, 2011) which means a higher antioxidant activity. In FRAP assay, a higher value of ferric reducing ability (mM Fe (II)/g dry sample) indicates a strong antioxidant activity (Wong et al., 2006). Thus, both the results of the DPPH-RSA and FRAP assays in the present study indicated that lower $\mathrm{N}$ application and successive harvesting increased the antioxidant activity of the grass. This phenomenon is probably due to the presence of various phenolic and flavonoid compounds in the grass. Fernandez-Panchon et al. (2008) reported that those compounds contribute to a better antioxidant activity of a plant. In fact, in this study, there was a significant negative correlation between TPC and $\mathrm{IC}_{50} \mathrm{DPPH}$ and between TFC and $\mathrm{IC}_{50} \mathrm{DPPH}$, but a significant positive correlation between TPC and FRAP and between TFC and FRAP (Table 2), indicating that the increment of TPC and TFC in the grass due to the treatments has led to the higher antioxidant activity of the grass.

\section{Conclusions}

The fertilizer type, fertilizer application rate (as $\mathrm{N}$ rate) and successive harvesting could increase dry matter yield, phytochemical contents and antioxidant activities of $C$. dactylon, in specific treatments. Specifically, there is a valuable gain to use those treatments to manipulate the production and accumulation of bioactive compounds of $C$. dactylon for pharmaceutical purposes.

\section{Acknowledgements}

This study was funded by the Ministry of Higher Education, Malaysia (Grant code: FRG0340-STWN1/2013).

\section{References}

Abdullah SY, Gobilik JA, Chong KP (2012). Preliminary phytochemical study and antimicrobial activity from various extract of Cynodon dactylon (L.) Pers. (Bermuda) against selected pathogens. International Journal of Pharmacy and Pharmaceutical Sciences 4(5):227-230.

Al-Humaid AI (2005). Effects of compound fertilization on growth and alkaloids of datura plants. Journal of Plant Nutrition 27(12):2203-2219. AldousDE, Wilson JR (1999).International Turf Management, Routledge. Amaglo NK, Timpo GM, Ellis WO, Bennett RN (2007). Effect of spacing and harvest frequency on the growth and leaf yield of moringa (Moringa oleifera Lam.), a leafy vegetable crop. Ghana Journal of Horticulture 6:33-40.
Barroso, MR, Martins N, Barros L, Antonio AL, Rodrigues MÂ, Sousa MJ, Santos-Buelga C, Ferreira ICFR (2018). Assessment of the nitrogen fertilization effect on bioactive compounds of frozen fresh and dried samples of Stevia rebaudiana Bertoni. Food Chemistry 243:208-213.

Benzie IF, Strain JJ (1996). The ferric reducing ability of plasma (FRAP) as a measure of "antioxidant power": the FRAP assay. Analytical Biochemistry 239(1):70-76.

Brasileiro BG, Leite JPV, Casali VWD, Pizziolo VR, Coelho OGL (2015). The influence of planting and harvesting times on the total phenolic content and antioxidant activity of Talinum triangulare (Jacq.) Willd. ActaScientiarum. Agronomy 37(2):249-255.

Chandel E, Kumar B (2015). Antimicrobial activity and phytochemical analysis of Cynodon dactylon: A review. Journal of Pharmacy and Pharmaceutical Sciences 4(11):515-530.

Dixon RA, Paiva NL (1995). Stress-induced phenylpropanoid metabolism. The Plant Cell 7(7):1085-1097.

Farshchi HSK, Arani MA, Nemati SH (2014). Phytochemical and Morphological attributes of St.John's Wort. Notulae Scientia Biologicae 6(3):326-330

Fernandez-Panchon MS, Villano D, Troncoso AM, Garcia-Parrilla MC (2008). Antioxidant activity of phenolic compounds: from in vitro results to in vivo evidence. Critical Review in Food Science and Nutrition 48(7):649-671.

Fook YC, Kheng YS (2009). Antioxidative and antibacterial activities of Pangium edule seed extracts. International Journal of Pharmacology 5(5):285-297.

GholamhosseinpourZ, Hemati K, Dorodian H, Bashiri-Sa Z (2011). Effect of nitrogen fertilizer on yield and amount of alkaloids in periwinkle and determination of Vinblastine and Vincristine by HPLC and TLC. Plant Sciences Research 3(2):49.

GobilikJ,Jerome V,DavidD (2013). Preliminary selection of some ecotypes of Cynodon dactylon (L.) Pers. in Sabah, Malaysia, for turfgrass use. Journal of Tropical Biology \& Conservation 10:51-66.

Gull J, Sultana B, Anwar F, Naseer R, Ashraf M, Ashrafuzzaman M (2012). Variation in antioxidant attributes at three ripening stages of guava (Psidium guajava L.) fruit from different geographical regions of Pakistan. Molecules 17(3):3165-3180.

Hallmann E, Rembiałkowska E (2012). Characterisation of antioxidant compounds in sweet bell pepper (Capsicum annuum L.) under organic and conventional growing systems. Journal of the Science of Food and Agriculture 92(12):2409-2415.

Hassan SA, Mijin S, Yusoff UK, Ding P, Wahab PEM (2012). Nitrate, ascorbic acid, mineral and antioxidant activities of Cosmos caudatus in response to organic and mineral-based fertilizer rates. Molecules 17(7):7843-7853.

Ibrahim M H, Jaafar HZE, Karimi E, Ghasemzadeh A (2013). Impact of organic and inorganic fertilizers application on the phytochemical and antioxidant activity of Kacip Fatimah (Labisia pumila Benth). Molecules 18(9):10973-10988.

Ilupeju EAO, Akanbi WB, Olaniyi JO, Lawal BA, Ojo MA, Akintokun PO (2015). Impact of organic and inorganic fertilizers on growth, fruit yield, nutritional and lycopene contents of three varieties of tomato (Lycopersicon esculentum (L.) Mill) in Ogbomoso, Nigeria. African Journal of Biotechnology 14(31):24242433. 
136

Jacobo-Velázquez DA, González-Agüero M, Cisneros-Zevallos L (2015). Cross-talk between signaling pathways: the link between plant secondary metabolite production and wounding stress response. Scientific Reports 5:8608.

Kedare SB, Singh RP (2011). Genesis and development of DPPH method of antioxidant assay.Journal of Food Science and Technology 48(4):412-422.

Khlifi D, Hayouni EA, Valentin A, Cazaux S, Moukarzel B, Hamdi M, Bouajila J (2013). LC-MS analysis, anticancer, antioxidant and antimalarial activities of Cynodon dactylon L. extracts. Industrial Crops and Products 45:240-247.

Manyawu GJ, Chakoma C, SibandaS, Mutisi C, Chakoma IC (2003). The effect of harvesting interval on herbage yield and nutritive value of Napier grass and hybrid Pennisetums. Asian Australasian Journal of Animal Sciences 16(7):996-1002.

Mary JAL, Nithiya T (2015). Effect of organic and inorganic fertilizer on growth, phenolic compounds and antioxidant activity of Solanum nigrum . L. Journal of Pharmacy and Pharmaceutical Sciences 4(5):808822.

Mohadjerani M, Tavakoli R, Hosseinzadeh R (2014). Fatty acid composition, antioxidant and antibacterial activities of Adonis wolgensis L. extract. Avicenna Journal of Phytomedicine 4(1):24.

Murali KS, Sivasubramanian S, Vincent S, Murugan SB, Giridaran B, DineshS, Sathishkumar R(2015). Anti-chikungunya activity of luteolin and apigenin rich fraction from Cynodon dactylon. Asian Pacific Journal of Tropical Medicine 8(5):352-358.

Nagori BP, Solanki R (2011). Cynodon dactylon (L.) Pers: A valuable medicinal plant. Research Journal of Medicinal Plants 5(5):508-514.

Naguib AEM M, El-Baz FK, Salama ZA, Abd El Baky Hanaa H, Ali HF, Gaafar AA (2012). Enhancement of phenolics, flavonoids and glucosinolates of broccoli (Brassica olaracea, var. Italica) as antioxidants in response to organic and bio-organic fertilizers. Journal of the Saudi Society of Agricultural Sciences 11(2):135-142.

Onofrei V, Burducea M, Lobiuc A, Teliban GC, Ranghiuc G, Robu T (2017). Influence of organic foliar fertilization on antioxidant activity and content of polyphenols in Ocimum basilicum L. Acta Poloniae Pharmaceutica 74(2):611-615.

Onyeonagu CC, Ukwueze CC (2012). Anti-nutrient components of guinea grass (Panicum maximum) under different nitrogen fertilizer application rates and cutting management. African Journal of Biotechnology 11(9):2236-2240.

Petropoulos S, Fernandes Â, Karkanis A, Ntatsi G, Barros L, Ferreira IC (2017). Successive harvesting affects yield, chemical composition and antioxidant activity of Cichorium spinosum L. Food Chemistry 237:8390.

Rivai RR, Wardani FF, Zulkarnaen RN (2017). The effect of NPK fertilizer and planting media on plant growth and saponin content of the medicinal plant Anchomanes difformis. Nusantara Bioscience 9(2):141145.
Salminen SO, Grewal PS, Quigley MF (2003). Does mowing height influence alkaloid production in endophytic tall fescue and perennial ryegrass? Journal of Chemical Ecology 29(6):1319-1328.

Singleton VL, Orthofer R, Lamuela-Raventós RM (1999). Analysis of total phenols and other oxidation substrates and antioxidants by means of Folin-Ciocalteu reagent. Methods in Enzymology 299:152-178.

Shamsa F, Monsef H, Ghamooshi R, Verdian-rizi M (2008). Spectrophotometric determination of total alkaloids in some Iranian medicinal plants. Thai Journal of Pharmaceutical Science 32:17-20.

Sudha A, Srinivasan P (2013). Physicochemical and phytochemical profiles of aerial parts of Lippia nodiflora L. International Journal of Pharmaceutical Sciences and Research 4(11):4263.

Tavarini S, Sgherri C, Ranieri AM, Angelini LG (2015). Effect of nitrogen fertilization and harvest time on steviol glycosides, flavonoid composition, and antioxidant properties in Stevia rebaudiana Bertoni.Journal of Agricultural and Food Chemistry 63(31):70417050.

Turgeon AJ (2008). Turfgrass Management. (8th ed). Upper Saddle River: Pearson Education International.

Vashisth T, Olmstead, MA, Olmstead J, Colquhoun TA (2017). Effects of nitrogen fertilization on subtropical peach fruit quality: organic acids, phytochemical content, and total antioxidant capacity.Journal of the American Society for Horticultural Science 142(5):393-404.

Vinther FP (2006). Effects of cutting frequency on plant production, Nuptake and $\mathrm{N} 2$ fixation in above-and below-ground plant biomass of perennial ryegrass-white clover swards. Grass and Forage Science 61(2):154-163.

War AR, Paulraj MG, Ahmad T, Buhroo AA, Hussain B, Ignacimuthu S, Sharma HC (2012). Mechanisms of plant defense against insect herbivores. Plant Signalling and Behaviour 7(10):1306-1320.

Wong CC, Li HB, Cheng KW, Chen F (2006). A systematic survey of antioxidant activity of 30 Chinese medicinal plants using the ferric reducing antioxidant power assay. Food Chemistry 97(4):705-711.

Xia P, Guo H, Zhao H, Jiao J, Deyholos MK, Yan X, Liu Y,LiangZ(2016). Optimal fertilizer application for Panax notoginseng and effect of soil water on root rot disease and saponin contents. Journal of Ginseng Research 40:38-46.

Zhang X, Li C, Nan Z (2011). Effects of cutting frequency and height on alkaloid production in endophyte-infected drunken horse grass (Achnatherum inebrians). Science China Life Sciences 54(6):567-571.

Zou Y, Liao S, Shen W, Liu F, Tang C, Chen CYO, Sun, Y (2012). Phenolics and antioxidant activity of mulberry leaves depend on cultivar and harvest month in Southern China. International Journal of MolecularSciences 13(12):1654416553. 